This is an Accepted Manuscript of an article published by Taylor \& Francis in Europe-Asia Studies on 29/11/2017, available online: http://www.tandfonline.com/doi/full/10.1080/09668136.2017.1385727

Accepted version downloaded from SOAS Research Online: http://eprints.soas.ac.uk/31139/

\title{
From protest to party: horizontality and verticality on the Slovenian Left
}

Alen Toplišek \& Lasse Thomassen

\begin{abstract}
This article analyses the politics of horizontality - a key characteristic of recent forms for protest and activist citizenship - through the case of the 2012-13 protests in Slovenia. The Slovenian case is illustrative because we can trace the emergence of the Initiative for Democratic Socialism and, subsequently, the United Left from protest through movement to party. Since we believe that horizontality and verticality are present in both movements and parties, we argue against a simple opposition between movements and parties. In particular, we focus on the reasons for the move from horizontalist ways of political organising to vertical structures.
\end{abstract}

\section{Keywords}

Horizontality; Initiative for Democratic Socialism; protest movement; Slovenia; United Left; verticality 


\section{Introduction: crisis, new forms of politics and horizontality}

The last two decades have seen a surge in the interest in activist citizenship (Isin 2009) and new forms of protest (Day 2005; della Porta et al. forthcoming 2017; Gilbert 2014; Maeckelbergh 2009; Sitrin and Azzellini 2014; Tormey 2015). This should be understood in light of the crisis of traditional forms of politics and representative institutions, including political parties. Across the world, and also in Europe, activists have opposed the vertical politics of institutions and parties in the name of horizontalist forms of organising. This was the case in the alter-globalisation movements and, from about 2011 onwards, in movements such as the Spanish and Greek indignados, Occupy, the Gezi protests in Turkey, and many others. Activists claimed that the crisis of representative democracy was a result of the way in which institutions and vertical forms of politics silence the voices of large parts of the population. The solution is then to do politics differently, and, although only one among other concepts and practices, horizontality is a key part of that (Maeckelbergh 2009; Sitrin and Azzellini 2014; Tormey 2015). This debate has a long history - think, for instance, of debates among communists and socialists at the beginning of the $20^{\text {th }}$ century about the roles of movements and parties; or the way new social movements challenged the political system from the 1960s onwards. Echoing earlier debates, the protest movements of the last two decades have often been met with the critique that, without going vertical, the protests will have no lasting effect. In some cases, political parties on the radical left have sought to channel the demands of the activists into the political system, most famously in the case of Syriza in Greece and Podemos in Spain.

Activists and commentators tend to oppose horizontality and verticality, with protests and movements on the side of horizontality and parties on the side of verticality. Here verticality refers both to hierarchical relations within the movement and to the relations between the movement or the party and state institutions. The opposition is both analytical 
and normative: for instance, that the new protest movements are horizontal in their structure, and that it is a good thing too (Day 2005; Sitrin and Azzellini 2014; Tormey 2015; critically, see Errejón and Mouffe 2016; Fisher 2013; Gilbert 2014; Mouffe 2013; Srnicek and Williams 2015). In this paper, we analyse the case of Slovenia to argue two things. We make the analytical argument that there is always both horizontality and verticality, and that the two are intrinsically linked (compare Kioupkiolis 2010; Lorey 2013). The question is then how horizontality and verticality are negotiated across protests, movements and parties. This also serves as a counterpoint to any simple opposition between movements and parties. We also make the normative argument that the entwining of horizontality and verticality is not a bad thing, and that a form of 'movement party' is the best response to the crisis of representative politics.

The case of Slovenia is interesting because it has received less attention among academic commentators despite similarities with bigger countries such as Greece and Spain (on Slovenia and neighbouring countries, see Horvat \& Štiks 2015; Kirn 2014; Kraft 2015; Krašovec 2013; Musić 2013; Razsa \& Kurnik 2012; Štiks 2015). What justifies a closer examination of the Slovenian case is, above all, the pattern of the movement from protest through movement to party. The responses to the developments in Slovenia were the wellknown complaints of the organised Left that protests and movements are ineffective, and the reverse complaints by protesters about the 'verticalisation' of the movement when its demands were taken up by a political party. Our analysis is chronological and follows the movement from protest through movement to party, but we challenge the way this movement is usually understood as a simple move from horizontality to verticality.

The Slovenian protests that took place between 2012 and 2013 were first spurred by corruption charges against the mayor of Maribor, the second biggest city in Slovenia, and later intensified by the release of an anti-corruption commission report accusing the then 
Prime Minister, Janez Janša, of having failed to report assets. One of the protest groups eventually resulted in the creation of Iniciativa za demokratični socializem (the Initiative for

Democratic Socialism [IDS]), which later became part of Združena levica, the newly created the United Left political party.

The 2012-13 Slovenian protests could easily be grouped together with other similar popular reactions that took place in Europe after the financial crisis, for example the 2011 anti-austerity movements in Spain and Greece, the 2012-15 Romanian and the 2013-15 Bulgarian protests, and the 2014 protests and occupations in Bosnia (Horvat and Štiks 2015; Štiks 2015). They all share an anti-establishment orientation, with the movements made up of diverse groups of individuals, indignant towards the political and economic elites for being unable to provide decent living standards following the 2008 financial crisis. Another feature unites all six countries in their political experience: the elite-led transition from an authoritarian regime to representative democracy. With their own idiosyncratic nuances, the protests challenge the official narrative of a successful transition and interrogate the role of the national political class in skewing the transition in favour of vested interests (Kraft 2015, pp. 201-5; Krašovec 2013; Musić 2013).

In order to analyse the ways in which horizontality and verticality were interlinked and negotiated, we first develop our theoretical and analytical framework. We do so through a critical analysis of the work of Marina Sitrin (Sitrin 2006; 2012; 2014; Sitrin and Azzellini 2012; 2014) who has written extensively about horizontality in new protests movements.

\section{Politics between horizontality and verticality}

The term horizontality has become popular among political theorists and activists as a way to describe and make sense of new forms of activist citizenship and the ways in which new political and social movements organise themselves. It is used, for instance, to characterise 
the alter-globalisation movements of the 1990s and 2000s, the Occupy movements of 2011 and many locally based movements. Many activists in the Slovenian movements we analyse here also represented themselves as engaged in horizontal politics, at least initially. In brief, horizontality refers to relationships organised non-vertically, without leaders and without a privileged centre. In the words of Marina Sitrin and Dario Azzellini (2014, p. 17), horizontality 'is a dynamic social relationship that represents a break with the logic of representation and vertical ways of organizing. This does not mean that structures do not emerge, as they do with mass assemblies and autonomous governance, but the structures that emerge are non-representational and non-hierarchical' (see Srnicek and Williams 2015, pp. 26-9 for an alternative definition). Our argument is two-fold: first, that there is no horizontality without verticality, that is, there are no purely horizontal relations; and, second, that it is possible to understand this sort of movements as caught in a tension between horizontality and verticality, which is negotiated differently in different contexts and by different agents.

Arguably the most developed account of, and argument for, horizontality is that of Marina Sitrin, who connects the concept of horizontality to contemporary movements such as Occupy and the indignados in Spain and Greece (Sitrin 2006; 2012; 2014; Sitrin and Azzellini 2012; 2014). Sitrin is squarely on the side of horizontality as opposed to verticality. Our intention here is not to revert this oppositional hierarchy between horizontality and verticality, but to subvert it. Engaging critically with Sitrin's work helps us develop the theoretical and analytical lens through which we will analyse the Slovenian case. We use Sitrin’s work as a stepping stone for developing a theoretical framework, and, as we will show, her account of horizontality presents certain tensions that are also evident in the discourses of the political activists. 
Sitrin opposes horizontality to verticality. Horizontality is a way to characterise the relationships between individuals and groups within a movement. A horizontalist movement is one that is horizontally organised without leaders and without a centre. Building on Sitrin’s use of spatial metaphors, one might think of such a movement as a flat network structure where individuals or groups form the nodes in the network.

Sitrin connects horizontality to other concepts used to characterise these movements. Autonomy is one such concept, and it refers to the relationship the movement takes up vis-àvis the state. Rather than making demands to the state, and rather than seeking to take over the state, which would assume the legitimacy of the state as an agent of social change, horizontalist movements withdraw from the state in order to safeguard the horizontality of the movement. Engaging directly with the state involves the danger of co-optation, but even when co-optation is avoided, the hierarchy and language of the state tend to be reproduced within a movement when it accepts funding from the state (Sitrin 2012, pp. 192-8; Sitrin and Azzellini 2014, p. 33; see also Day 2005). Sitrin also connects horizontality to selforganisation: only a movement where members self-organise can be horizontal. Together horizontality, autonomy and self-organisation imply a rejection of representative structures and of the state. The alternative to these forms of 'power-over' is the 'power-with' of movements that organise horizontally, withdraw from the state and self-organise (Sitrin 2012, pp. 102-5). Only then is it possible for people to speak for themselves and for their voices to be heard.

Rather than opposing horizontality in the name of the (alleged) efficacy of vertical forms of politics, we propose that a more fruitful critique starts by asking about the conditions of possibility for the creation of horizontal relations. We will thus try to identify the places in Sitrin's text - and, later, in the discourse of the Slovenian protesters and 
movements - where verticality is not simply opposed to horizontality, but becomes the condition of possibility for horizontality to exist.

The first thing to note is that horizontality is a relationship that has to be created and sustained. Sitrin's question is precisely how horizontality can be made possible and made to last; this is what she calls the question of success (Sitrin 2012, p. 3). We are not dealing with some form of spontaneism - 'Horizontal spaces do not just occur spontaneously.' (Sitrin 2012, p. 79) - nor can we take horizontality as a given once it has been established. The horizontality of the movements has to be created out of a social and political space that is at least in part vertically structured, and it has to be so by subjects who have been shaped by that vertical space. Those subjects have been shaped by more or less vertical relationships in the family, the workplace, political and social movements, and so on. They must learn horizontality; only then is it possible to explain how they institute horizontal relationships and sustain them (Sitrin 2012, pp. 34-5, 73, more generally chapter 4; Sitrin and Azzellini 2014, p. 18).

In Sitrin’s (2012, p. 3) words, a crisis of the formal structures of power in a society opens the social space for people 'to come together, look to one another, and create new supportive relationships' - that is, to self-organise in horizontal ways. This is what happened in Slovenia where the introduction of speedometers in Maribor and the corruption charges brought against the Prime Minister set off a series of protests, which were in turn seen as the expression of a wider crisis of the Slovenian political and economic system. The protesters gathered in public squares to call political representatives to account, and their coming together created a space for thinking and organising alternative ways of doing politics. The crisis opens up a space where horizontality can emerge. At the same time, for Sitrin (2012, p. 61), the horizontal space makes possible the creation of new subjectivities. There is, thus, a 
mutual dependence between the structure (horizontal spaces) and the agents (subjects capable of creating horizontal spaces).

If horizontality is something to be created and defended by individuals, those individuals must agree on what horizontality means and the means to create and defend it. There will be disputes about what horizontality is, and how to realise it; 'declaring something horizontal does not make it so' (Sitrin 2012, p. 75). If that is the case, then horizontality will be, as Sitrin (2012, p. 74) argues, a process. All we have are different representations or practices of horizontality, not horizontality as such and never as an objective state of affairs where we can say that this is horizontality.

Finally, horizontality must be defended, above all against vertical forms of power. For instance, it must be defended against disruption by state agents and organisations of the old Left (Sitrin 2012, pp. 67, 77). Horizontality cannot be all-inclusive as it necessarily relies on exclusion of those who are against horizontality; without this exclusion, there can be no horizontality, at least not in the long run (Sitrin 2012, pp. 81-2). Here we cannot ignore the difficulty of defending horizontality when differences exist over the meaning of it. To defend horizontality is always to defend a particular meaning of horizontality, and so there is no horizontality without some closure and exclusion - the latter are the very conditions of possibility of horizontality.

What should be clear by now is that horizontality and verticality cannot be disentangled. Horizontal movements cannot not relate to the rest of society and the vertical structures of it. The horizontalist movements have numerous points of contact with vertical structures of power, whether those are the institutions of the state or other organisations and movements within civil society. As Sitrin herself acknowledges: 'It would be an illusion to think that a 'happy island of horizontalism' could be created in the middle of the sea of capitalism’ (Sitrin and Azzellini 2014, p. 17; also Sitrin and Azzellini 2012, p. 40). If we 
think of horizontality and verticality in terms of spaces of horizontal and vertical relations respectively, the point is that those spaces are necessarily entangled with one another.

This is not only a matter of the relations between a movement and the rest of society. It is also the case that vertical relations remain within the movements - think, for instance of the question of informal leaders (Sitrin 2012, p. 78). In the case of the 2012-13 Slovenian protests, the movement officially did not select a leader, and, in their press releases, the undersigned were always the individual protests groups and never the individual leaders. Yet, the most visible representative of the movement was the organiser of the 'All-Slovenian People’s Uprising’ protest group, Uroš Lubej, and the problem of the informal leaders was still present. In this case, the relationship between hierarchies within the movement (leaders) and the vertical structures of the external environment is closely connected because the movement's internal and external communication is mediated by media that are often vertical in their structure. Whether the protesters liked it or not, the media networks themselves identified the speakers of/for the movement, invited them to give interviews and appear on panel discussions. From within the movement, the same process of selection took place through the division of tasks and the role of speakers at public assemblies.

Horizontality is also entangled with verticality because the individuals who engage in horizontalist movements have lives outside those movements, lives in which they engage in non-horizontal relations. But, apart from this, there is a more profound reason why, even in the most horizontal of horizontalist movements, we find relations of verticality, and that is because, as argued above, verticality is the condition of possibility of horizontality. That is, horizontality is made possible by some element of verticality; there is no horizontality without verticality. It may be possible to overcome particular obstacles that one encounters when practicing horizontality, but there will always be some verticality that prevents the full realisation of horizontality. Although horizontality and verticality may be opposed, it is a 
form of opposition where one (verticality) also makes possible the other (horizontality). And there are no pure horizontal relations within a movement because the condition of possibility of horizontality is some verticality - in other words because horizontality has to be instituted and sustained.

We are not arguing that we should give up on horizontalist, autonomist or selforganising movements; on the contrary, these have a very important role to play in any democracy worth the name. Rather, for the activists and the movements, the central question becomes one of how horizontality and verticality are articulated together, and here there is no blueprint for how activists and movements should proceed. That is something they must figure out themselves, and each time in a new way.

As we will show in the case of Slovenia, the different articulations of horizontality and verticality will be particularly evident when moving from protest and other forms of noninstitutional activism to more formal organisation, especially party politics. Having said that, one should avoid a simple opposition between protest and parties because horizontality and verticality are present in both. In the following, we let the activists speak through the dynamic between horizontality and verticality. This dynamic is partly imposed on the material we analyse, but it emerges from engaging with the activist discourses and is itself articulated by the activists themselves. ${ }^{1}$ In a process where the self-representations of the activists as well as our representations of them are open to contestation, we hope to make

\footnotetext{
${ }^{1}$ We have relied on the following news outlets for protesters' discourses, facts and background information: Žurnal24, RTVSLO, Delo, Mladina, Siol.net and 24ur.com. Additionally, we have analysed the manifestos and press releases of the main protest

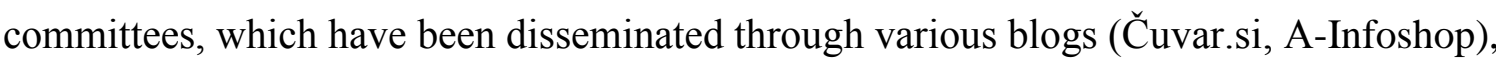
forums, and social media (Facebook groups and pages).
} 
possible a critical engagement with the movements without unilaterally imposing an external yardstick on them, and this is also a way to bring out the heterogeneity of the movements.

\section{A brief history of Slovenian activism}

In order to understand how the relationship between horizontality and verticality played out during the 2012-13 protests and during the emergence of the Initiative for Democratic Socialism (IDS) and the United Left, we need to acknowledge the history of horizontalist practices preceding the protests. The following brief history of Slovenian activism and radical politics is merely a snippet taken out of a longer and more extended context reaching back to the days of civic activism in ex-Yugoslavia. ${ }^{2}$ We can situate the beginnings of organised, and more coherent, activism a decade after the independence of Slovenia, which at the time was still undergoing the transition to join the rest of European liberal democracies. Rasza and Kurnik (2012, p. 245) identify the alter-globalisation movement of the late 1990s and early 2000s as a key period when 'some activists in Ljubljana were first politicized'. The alterglobalisation campaigns were quickly followed by protests against the US invasion of Iraq (March 2003) and Slovenia’s bid to become a member of NATO (May 2004) (Kuzmanić 2002; Zadnikar 2002; Gregorčič 2005; Zdravković 2014). More generally, the mid-2000s in Ljubljana were characterised by a 'changing landscape of the city and its outskirts, the loss of the public realm through privatisation, the authoritarian management of populations and practices and the reduction of diversity all for the logic of profit’ (Kurnik and Beznec 2009, p. 45). In response to this elite-led neoliberal transformation of the Slovenian capital, activists occupied and reanimated an abandoned bicycle factory, Rog, in order to create a space for

\footnotetext{
${ }^{2}$ For more on civil society and activism in the former Yugoslavia, see Lukšič (1990), Figa (1997), Jelušič (2006), Vodovnik (2014) and Fink-Hafner (2015).
} 
mobilising collective resistance and disrupting the corporatist vision of Ljubljana (Kurnik and Beznec 2009, p. 47). The occupied space served as a platform for the production of alternative forms of life and localised resistance through organised assemblies and the active participation of its users (Kurnik and Beznec 2009, p. 52). Struggles over citizenship and belonging came to dominate the Slovenian activist scene in the second part of the 2000s, with the horizontalist practices of direct action and decision-making being the main organisational structure (Rasza and Kurnik 2012, p. 245). However, these protest actions were small in scale and did not have a demonstrable effect beyond the scope of activist and academic circles.

The financial crisis of 2008 and the worsening of socio-economic conditions provided the fertile ground for protest movements around the globe on mass-scale. Inspired by the Arab Spring, the 15M movement in Spain and Occupy Wall Street, the Global Day of Action on 15 October 2011 also kicked off protests and occupations in Slovenia. Activists in Slovenia gathered in Koper, Maribor and Ljubljana, where a group of participants occupied the square in front of the Ljubljana Stock Exchange. The 150 Movement, or Occupy Slovenia, provided a common public space for the critique of financial capitalism and for the 'collective capacity to manage our own lives and reconstruct society from below' (Razsa and Kurnik 2012, p. 252). It represented an autonomist moment of horizontal direct democracy. One of its slogans was 'No-one represents us!', and, in their self-understanding, it was 'a movement based on principles of direct democracy and direct action - horizontally, in network form' (Večer, quoted in Razsa and Kurnik 2012, p. 242).

The protests were thus clearly framed within the crisis of representation so that the solution to this crisis was to think of democracy in terms of direct and horizontally organised action. Already here we find a tension between horizontality and verticality that we will analyse in more depth below in relation to the 2012-13 protests. Take, for instance, the question of how to relate to the state. In their analysis, Razsa and Kurnik (2012, pp. 249-50) 
describe the dilemma faced by activists: on the one hand, making demands to the state and in terms of rights risks reproducing the very oppressive structures that the activists are struggling against; on the other hand, the activists must start from things as they are. Razsa and Kurnik and their informants describe this in terms of 'contradictions' that cannot be resolved, and their conclusion is that horizontality can be neither counterfactually assumed nor be taken as an absolute goal. In that case, we are dealing with a continuous and neverending negotiation between horizontality and verticality. Another and less obvious example is the activists' description of what they are doing as the creation of spaces, or frameworks, of encounter (Razsa and Kurnik 2012). These are spaces where, because they are autonomous and horizontalist, individuals and groups can come together and act in common. Yet, it is also clear that these are spaces that have to be carved out of a larger society of more vertical relations, that the spaces have to be defended against co-optation, and that they have to be protected against centrifugal forces by some common ground - thus introducing an element of verticality into them.

While the 150 occupation was mainly stationed in front of the Ljubljana Stock Exchange, the activists also helped mobilise students at the Faculty of Arts, University of Ljubljana, where the occupation lasted for three months from the end of November 2011 to January 2012. As Anej Korsika and Luka Mesec (2014, pp. 85-6) recount, the occupation of the faculty was successful in bringing together a wealth of experience from different participants, yet it failed to realise any of the demands put forward to the management. The same fate hit Occupy Slovenia three months later. Due to internal conflicts and protest fatigue, the occupation in front of the Ljubljana Stock Exchange ended in April 2012. Despite this, at the time when the protests broke out in 2012, many activists had thus already had some experience with horizontality. 


\section{The 2012-13 waves of protest in Slovenia}

Without this 'rather long prehistory to the Initiative [IDS]', where most of its 'active members were already active in the student movement, various student organizations, newspapers, fights against plans to implement tuitions’ (Korsika and Mesec 2014, p. 85), we cannot comprehend the role that past experience in horizontal practices of organising played in the 2012-13 Slovenian protests. Yet, as the case study will gradually reveal, horizontal practices of protests and movements themselves rely on vertical relations, both internally and in relation to the rest of society. Our observation goes against the common stance in much of the horizontalist and autonomist literature on the radical left in Slovenia, where the vertical conditions of active citizenship are often neglected by privileging horizontalism and associated ideas such as autonomy, spontaneity, prefiguration and non-domination (see Kuzmanić 2002; Gregorčič 2005; Rasza and Kurnik 2012; Kurnik 2013).

The first in the series of Slovenian protests and popular uprisings took place on 2 November 2012 in the second biggest city, Maribor, in front of the city hall. ${ }^{3}$ The protest was organised spontaneously by citizens themselves as a result of their mounting frustration with newly erected speedometers, managed through a public-private partnership. The 'AllSlovenian People's Uprisings', as they were called in the media and by the protesters themselves, were organised through the use of horizontal networks of communication, mostly Facebook, blogs and Twitter. Four weeks later, the protest movement grew to 20,000 people, calling for the mayor of Maribor, Franc Kangler, to step down. The protesters invented a

\footnotetext{
${ }^{3}$ For more on the material conditions for the emergence of protests in Slovenia and the socioeconomic consequences of governmental neoliberal policies, see Močnik 2003; Kirn 2014; Korsika and Mesec 2014; Musić 2013; and Slameršak 2013.
} 
reverberating slogan that became symbolic for the whole movement as it quickly spread to other parts of the country: 'Gotof je!/Gotovi so!’ ('He’s finished!/They’re finished!’).

While the first protests in Maribor were mostly self-organised through the social media, as the protests reached the capital of Ljubljana and grew into a more sustained movement, existing civil initiatives and other organisations joined the movement. The protest movement became more and more heterogeneous in composition: from students, lecturers and trade unions to precarious workers, pensioners, anarchists, ecologists and socialists (Gračner 2013). The growing protest movement thus also came to be seen as an opportunity for already existing social groups to join newly formed protest groups and contribute to setting the protesters' agenda. The coordination of activities and protests took place through the movement's General Assembly, which was supported by smaller coordination groups, such as the ‘All-Slovenian People’s Uprising’ Committee, Committee for Social Justice and Solidarity, the Coordination Committee of Slovenian Culture, the Committee for Direct Democracy, the Movement of the Responsible, a group of young digital savvy students and academics called Today is a New Day, Direct Democracy Now!, and the Initiative for Democratic Socialism (Gračner 2013).

The first protest in Ljubljana took place on 27 November 2012. ${ }^{4}$ The second was held only three days later and the organisers helped mobilise around 10,000 people. Five more waves of protests took place between December 2012 and March 2013, with the biggest one taking place on the Slovenian Culture Day, 8 February 2013, gathering more than 20,000 people. Between December and January, the calls from the media and other vertical structures to put forward demands and establish a political party became hard to ignore. As one protester described the situation: in December no-one knew what demands to put 
forward, in January different committees were already busy drafting programmes, and in February, the protest groups were in the fragmentary phase of forging alliances (anonymous participant in Zdravković 2014, p. 61). The discussions among protesters during this time revolved around the purpose, future and organisation of the movement, including whether there was a need for a united position and leaders, and whether the movement should bypass the vertical structures of representative politics, and, if so, what its relationship should be with the new political parties that might emerge from the movement (Zdravković 2014, pp. 59-61). The tension between horizontality and verticality was therefore very much at the centre of protesters' deliberations during this time.

By February 2013 the protesters compiled a list of demands to be debated and voted upon through online discussion groups, which included a key demand for Janez Janša’s government to step down, the establishment of a transitory government and new elections within six months (Čuvar 2013). Among the more substantial demands for the transitory government, the protesters listed the following: (1) a public debate on the necessary changes to the legal and economic order; (2) end to austerity and structural reforms; (3) reform of the judiciary; (4) equalising the status of parliamentary and extra-parliamentary movements; and (5) recall elections and more direct democracy (Radio Krka 2013). As can be noted, some demands were much more anti-systemic than others. Although the final draft represents a unified and common position of various groups participating in the protests, it is an amalgamation of differing and, at times, ideologically conflicting interests of the participating groups. The different positions within the protest movement could be categorised into the following strands: (1) the moralist strand, which seeks ethical purity through rule of law and going beyond ideological divisions; (2) the centre-left liberal defence of the diminishing social democratic consensus; (3) the radical left strand extending the critique to the whole political and economic system; and (4) the strand calling for change of the existing electoral 
democracy through means of direct democracy. These different strands took different views of the need for vertical structures and the need to engage directly with state institutions. ${ }^{5}$

At the beginning of the protests, the main goal was to put pressure on the political elites to change the direction of Slovenian politics, mired in corruption, especially at the local level of government. According to the movements' communiques, the protests were not merely anti-government, aimed solely at the then Prime Minister Janez Janša or his political party, but against 'the whole Slovenian political caste’ (Čuvar 2013). The protest organisers took this position of externality in order to defend the spontaneous nature of the protests and to emphasise the fact that they were not orchestrated by oppositional political parties. This was crucial at the time in order to effectively counter the accusations that the protests were organised by the opposition left-wing parties. Moreover, the refusal to be aligned with either the right or the left was similar to that of the Indignados in Spain: the left and the right were seen as equally corrupt, and so the protest movement portrayed themselves as above established politics and as neither left nor right.

The rapid succession of events between February and April 2013 had important consequences for the maintenance of this united position among the different protest committees. A key mobilising factor was the publication of an anti-corruption commission report in January, accusing the Prime Minister, Janez Janša, of failing to properly report his assets to the commission. As the protests intensified in numbers, so did the pressure on Janez Janša’s coalitional partners to leave the government. On 27 February, Janez Janša was ousted, following a parliamentary vote of no confidence. The toppling of the government was seen as

\footnotetext{
${ }^{5}$ Similar observations on the classification of protesters' demands were also made by Krašovec (2014, pp. 314-5) and Kirn (2014, pp. 120-1).
} 
a key success for the movement, yet at the same time it also marked the beginning of its end. This led the different protest committees to consider the future direction of the movement.

The united position of the movement started to break down after Janez Janša was forced to step down as Prime Minister, and when it became clear that other established political parties, especially the centre-left Social Democrats and Positive Slovenia, were not going to call for early elections. This is when the differences about the way forward for the protest movement between the different groups started to become starker. There was a clear division over the right political strategy and the aims of different protest committees. The two main responses that formed across the protest movement were: (1) staying active in local communities and civil society (horizontally), but not take part in party politics; and (2) establishing a hybrid political movement which would act on the ground in civil society (horizontally) and through new political parties (vertically) at different levels of governance (local, national and EU level). The performative group of artists, musicians and other creative individuals, Protestival, was premised solely on horizontal ways of organising, and the same applies to the City Assembly Initiative in Maribor which acted as a local neighborhood platform for the self-organisation of Marbor's citizens in tackling common local issues (Nemac 2014). On the other hand, the ‘All-Slovenian People’s Uprising’ Committee, the Committee for Social Justice and Solidarity and the Network for Direct Democracy chose to adopt more vertical ways of organising in order to be able to contest established political parties in the formal institutions of representative politics. So did the Initiative for Democratic Socialism, but because of their clear ideological orientation and radical aims in their political manifesto (e.g., an end to austerity, workers’ management of state-owned corporations, an active role of the state in industrial policy and economic coordination [IDS 2015, pp. 30-5]), other main protest groups were reluctant to form a wider coalition with them. 
Splits also occurred within protest committees themselves. This division is well exemplified by the split in the 'All-Slovenian People’s Uprising' Committee between two of the committee organisers, Uroš Lubej and Peter Petrovčič. In an interview for the Slovenian daily Primorske novice (Littoral News) a year after the protests, Petrovčič admitted that the main reason behind the failure to form a united front against all established political parties was that they could not come to an agreement on how to proceed (Vidrih 2014). Some committee organisers, like Petrovčič, believed that the protest movement should demand the removal of all political elites, whereas others, together with Lubej, were satisfied with toppling Prime Minister Janša's right-wing government. The first group took the position that all politicians and political parties bear responsibility for corruption and for the state of the economy in Slovenia, regardless of whether they are coming from the right or the left. While the second group agreed with this stance, they believed that the protest comittee should focus on connecting with other protest comittees and use the momentum to build a new force in the Slovenian political space (Golob 2013). This division between sticking with the horizontal forms of activism or adopting vertical ways of organising the protest movement was characteristic of the whole protest movement by summer 2013, which resulted in the dispersal of the protest movement's momentum. Some of that energy was channelled into, or rather multiplied by, the decision of some parts of the movement to adopt more vertical structures of organisation.

Uroš Lubej and the majority of protestors from the 'All-Slovenian People’s Uprising' Committee joined the Committee for Social Justice and Solidarity and the Network for Direct Democracy, and together formed the Solidarnost (Solidarity) political party (Solidarnost 2016). In the electoral campaign for the early parliamentary elections, they formed a coalition with the Social Democrats, who were ironically also one of the targets of the protest movement. The Solidarity party failed to get any seats, however. Meanwhile, the Initiative 
for Democratic Socialism adopted a more hybrid structure of vertical and horizontal ways of organising than the Solidarity party. In the following, we will use the Initiative for

Democratic Socialism to illustrate the tension between horizontality and verticality in the quest to construct an alternative to neoliberal and representative politics.

\section{The emergence of the IDS and the United Left}

The Initiative for Democratic Socialism (IDS) was formed as a more coherent grouping of some of the movement's protesters and activists around a clear political-ideological project of a democratic and ecological socialism. Their base drew intellectual energy largely from academic and student Marxist thinkers of different hues working within the Workers and Punks’ University, an educational project run as part of the Peace Institute in Ljubljana, and the activist group Direct Democracy Now!. The valuable collective experience some of the activists gained in previous horizontalist radical actions provided the basis for 'a clear understanding ... that different and most importantly much stronger organizational forms are necessary' (Korsika and Mesec 2014, p. 86). This did not mean that they were ready to abandon their roots - instead the move was seen as a politically strategic multiplication and broadening of their impact. They still considered themselves primarily as a social movement, engaged in horizontalist practices and resistance, but with an added set of formal and vertical structures which can engage with and participate in the existing structures of established power, including political institutions (IDS 2016).

The Initiative for Democratic Socialism was first presented at a press conference in Ljubljana on 30 April 2013. In a critique of the moralist technocratic and liberal centre-left stances prevalent in the protest movement, the founding members made it clear that 'the current crisis is not a moral crisis or the crisis of the rule of law, but a crisis of capitalism' (RTVSLO 2013). They added that Maribor should not be viewed as the cause of the 
protesters' movement, but as its trigger. What provided the conditions for the uprising, as in other similar uprisings around the world, were wider structural reasons, such as 'increasing unemployment and precarious jobs, cutting of social services and transfers, decreasing of wages and manifest corruption’ (RTVSLO 2013). This demonstrates how the IDS articulated their critique in two ways: on the one hand, using Marxist class analysis, the problem was not with individual corrupt politicians, but in the system that conditions this type of behaviour. On the other hand, the struggle of Slovenian protesters is not an isolated incident, but connected to other similar protests that were taking place around the world, giving the protest group a unique internationalist perspective. Thus, when the ‘All-Slovenian People’s Uprising' Committee and the Committee for Social Justice and Solidarity were calling for replacing the current political class with experts that were not morally corrupt, IDS rejected this by arguing that capitalism as the dominant political economic system itself needs to be challenged. Moreover, the IDS did not only manage to build an effective critique of the system, but also an alternative, namely democratic socialism:

Capitalism ... needs to be replaced by a more rational system, which will be based on cooperation, social ownership of the means of production, democratic planning of production and aimed towards fulfilling the social needs of all, hence socialism. (Mesec in RTVSLO 2013)

The key message of the IDS was therefore that only by addressing the underlying class divide in society would the protest movement be able to solve the problems of widespread corruption in the Slovenian political system (ibid.). With regard to the organisation of the initiative, the first step was to build a wider movement, which would gather around these aims, and possibly lead to the emergence of a new political party sometime in the future. As 
Korsika and Mesec (2014, pp. 85-6) explain in their article on the developments within the IDS, ‘[p]rotests as such have definitely caused history to speed-up and processes that would otherwise demand much more time have unravelled rather quickly’. Less than a year later, and just a few months before the 2014 European Parliament and early National Assembly elections, the IDS was ready to begin 'the long march through the institutions' (IDS 2016). The activists viewed this step as a way to fundamentally democratise the representative institutions, so that 'they would serve the working people and not the interests of capital' (IDS 2016).

On 8 March 2014, the Initiative for Democratic Socialism formally established itself as a political party. At the same time, the IDS joined two other smaller and ideologically related parties, and this led to the establishment of the United Left political party. The rationale behind this move to more vertical ways of organising is provided in the following justification from their website:

On the basis of our achievements, and especially our failures and the limitations to our activist operations, we have increasingly come to the realisation that we need a more stable and organised form of operating. A decision was reached which acknowledged the need for operating within the centres of political power as well. We see the establishment of our party and our candidacy at the European elections in May 2014 as the next steps on the path of a broader and more organised movement. (IDS 2015, our translation)

This was viewed as a strategic move to combine horizontal ways of organising with vertical structures rather than as a rejection of the horizontal ways of organising, which was the predominant form of the IDS's operations during the 2012-13 wave of protests. In their 
manifesto, the IDS explicitly underscore the need to establish local networks and working groups around the country, the purpose of which would not be to rubberstamp the decisions of the party structures, but to provide a framework for self-organisation, participation and activism of local people (IDS 2015, 2016). Moreover, this strategic move is the result of a conscious decision on the part of the activists to expand the social impact of their activities, while acknowledging the dangers that vertical organisational structures entail:

[W]e perceive this as a political problem, [a] party must not be a goal in itself but only [the] means for achieving higher political goals. We do not want to build a classical bourgeois party that will be just one among many. Instead, we want to build a proper workers [sic] party that will be only an instrument of a wider and deeply rooted movement. (Korsika and Mesec 2014, p. 87)

One might expect a party programme that argued for democratic socialism, 'social ownership of the means of production' and 'democratic planning of production' to be connected to vertical forms of organisation. Indeed, this is how traditional parties on the Left have approached the matter, in terms of both the organisation of the struggle for these goals and the organisation of the new society. In the case of the IDS, however, democratic socialism is articulated with a different and less vertical form of party organisation. The relation between horizontality and verticality is thus understood more in terms of a mutually supportive relationship rather than a simple opposition (Workers and Punks’ University 2013, p. 38). The hybridity of such a relationship can only be maintained through an ongoing process of activist dedication and pragmatism, while avoiding falling into either the 'fetishism of the party’ or the 'fetishism of spontaneity' (Workers and Punks' University 2013, p. 38). The active members of the IDS use the terms 'organisation' and 'spontaneity' to 
characterise this relationship: 'only an appropriate organization can guarantee the political effectiveness of spontaneous impulses and thus prevent the dominant system from co-opting it, and only by maintaining a connection with spontaneous impulses, can we prevent the ossification of the organization and ensure its adaption to changing circumstances' (Workers and Punks’ University 2013, 39).

Although there is a tension between them, organisation and spontaneity, or verticality and horizontality, are thus not opposed, but two different aspects of the same whole. It goes beyond the relationship of horizontality to the party structure and to the structure of the political system, because the IDS are seeking to hegemonise not only the political system, but the wider network of social relations and structures. Thus, for instance, Korsika and Mesec (2014, p. 88) write of the need to 'establish all kinds of workers [sic] institutions' in order 'to contribute to building socialist hegemony’. Here, hegemony is understood as leadership through the creation of consent. This clearly has a vertical relationship to it, but the consent cannot simply be manufactured from above, but must be rooted in horizontal and vertical relations within civil society.

When it comes to the need for leadership and more professionalised organisation of a popular movement, a compelling question that needs attention is the seemingly irreconcilable tension behind the hybrid nature of the new political force that the United Left represents in the Slovenian political landscape. The way the United Left represents itself and wants to be perceived by ordinary people is not only in terms of offering an alternative set of policy proposals and a new ideological direction in politics. They also manifest an alternative form of organised politics where operating through a political party (at the national level through parliamentary assemblies, but also at the local level) is just one form of political organising The difference from the established mainstream parties lies in United Left's hybridity and interpenetration with their grassroots base. Despite the United Left having representatives 
elected at different levels of established governance structures, their internal structures are partly composed of less formalised processes of political deliberation and organisation, such as working groups, regional committees, general assemblies, street protests, consultations with the wider movement membership, and so on. Key policies, positions and press releases are all deliberated and decided upon collectively by the IDS membership, mainly through the working groups and regional committees. This work is facilitated by online applications, such as Google Groups and Documents, where members can sign up and contribute to shaping the United Left's internal documents.

What remains to be seen is how long this delicate relationship of hybridity will stay intact. By establishing a political party and gaining parliamentary representation, the IDS and the United Left have widened the ideological spectrum of Slovenian politics and gained valuable media access for the dissemination of otherwise marginalised ideas and initiatives that arise from civil society (e.g., marriage equality, animal welfare legislation, legalisation of marijuana and a universal basic income). However, the dynamics of parliamentary work, which tends towards centralisation and systematisation of internal decision-making, can clash with the more open and horizontal practices of civil society groups and social movements. This growing tension was the key reason for the stalemate at the second annual congress of the IDS in April 2016, where a fraction of the members successfully blocked the plans to transform the coalition of the United Left into a uniform party, but was ultimately defeated in a correspondence session following the congress. This leaves open the question of whether the hybrid relationship between the United Left as a party and social movements is only a temporary stage in the maturation of their political project or a sustainable structural solution to the crisis of representative politics. Together with other radical left parties in Europe, with Syriza and Podemos being the two most notable cases, the question of 'governing' and the inevitability of compromise-making along the way pose further challenges to the movement 
party model of radical left politics (della Porta et al. forthcoming 2017; Kriesi 2015; Mouffe 2014).

\section{Conclusion: From horizontal struggles to movement parties}

New forms of protest and activist citizenship have challenged the vertical structures of existing parties, unions and institutions, thereby opening up new ways of thinking and acting. A key part of this is the privileging of horizontality against the hierarchies of representative institutions and traditional organisations, including political parties. Rather than conceptualising the structures of protests, movements and parties in terms of a mutually exclusive opposition between horizontal and vertical ways of organising, we have proposed to view the different instances of political action as mutually reinforcing, yet still in a relationship of tension. We have tried to show this through critical analyses of, first, Marina Sitrin's extensive work on horizontality, and, second, the case of Slovenia. We found that while there was a greater degree of horizontality during the initial stages of protest and, conversely, a greater degree of verticality once the Initiative for Democratic Socialism and the United Left had been created, the activists were struggling with the tension between horizontality and verticality from the very beginning. At the end of the more horizontal protests in 2012-13, the strategy of the main protest committees was to maintain and multiply the effects of the horizontalist discourses and practices through the conscious use of vertical structures. This move was seen as key in bypassing the ephemerality of direct protest actions and harvesting the mobilising power of the protest movement. At the same time, the initial distancing of the protesters from established vertical practices and structures of representative politics was necessary for the autonomous development of the movement and its legitimation in the eyes of the wider public. Only in this way could the protesters draw a line between the old ways of doing politics and the potential for a new politics. 
Our conclusion resonates with recent work on social movements and parties where some scholars have also started to pay more attention to the interaction between movements and parties. If we no longer think of movements and parties as two different entities or political spaces, it then becomes necessary to reconceptualise the relationship between them. This is particularly important for contemporary politics on the European Left, with Syriza in Greece, Podemos in Spain, and Corbyn and Labour/Momentum in the United Kingdom as the most obvious examples of what Donatella della Porta calls 'movement parties' (della Porta et al. forthcoming 2017; see also Kitschelt 2006).

In her recent work on political movements, Chantal Mouffe has also pursued this line of argument, and we would suggest that her work is fruitful as a starting point for rethinking the relationship between movements and parties. Although at some points in her argument, Mouffe (2014) repeats the functionalist dichotomy between social movements and political parties that has dominated the social movement literature (for instance, see Mouffe 2014), in her more recent work on left-wing populism, she provides the theoretical stepping stones for establishing a synergy between electoral competition and social struggles. Noting the inadequacy of traditional hierarchical parties to absorb the plurality of democratic demands in our society, she proposes a new form of political organisation is needed which can articulate both horizontality and verticality:

We need a synergy between electoral competition and the wide range of struggles that take place in the social arena. It's clear that the democratic demands that exist in our societies cannot find an expression solely through the vertical party form, that they also need horizontal forms of expression. A new form of political organisation that articulates the two modes - that's how I conceive 'left-wing populism'. (Mouffe in Errejón and Mouffe 2016, p. 125; see also Mouffe 2013, pp. 126-7) 
Similarly, our analysis of the Slovenian case suggests that a simple division of labour between movements and parties, and between 'society' and 'politics', is unsound. Not only are horizontality and verticality closely entangled in any form of organisation - protest, movement or party - but there is a normative point here too about political parties that - like Syriza after the 2015 referendum - shift towards a more uniform and top-down structure, effectively cutting off vital ties with civil society groups and social movements. Horizontalist movements need to connect with vertical structures and use these for their own purposes, but vertical parties also need to stay plugged into horizontalist practices - also because this is a more effective way of generating social and political change. With the institutions of representative politics facing a mounting challenge from new populist forces in Europe and across the Atlantic, reconceptualising the relationship between movements and parties may very well be the much needed answer for amending the social contract.

\section{References}

Bokovoy, M., Irivine J. A. \& Carol, L. S. (eds) (1997). State-Society Relations in Yugoslavia, 1945-1992 (London: Palgrave MacMillan).

Caparini, M., Fluri, P. \& Molnar, F. (eds) (2006) Civil Society and the Security Sector:

Concepts and Practices in New Democracies (London, Lit Verlag).

Čuvar (2013) Odbor VLV se bo udeležil tribune v Cankarjevem domu, 27 January, available at: http://cuvar.si/manifest-vseslovenske-ljudske-vstaje, accessed 4 April 2016.

Day, R. (2005) Gramsci is Dead: Anarchist Currents in the Newest Social Movements (London, Pluto Press).

della Porta, D. \& Diani, M. (eds) (2015) The Oxford Handbook of Social Movements (Oxford, Oxford University Press). 
della Porta, D. et al. (forthcoming 2017) Movement Parties Against Austerity (Cambridge, Polity Press).

Errejón, Í. \& Mouffe, C. (2016) Podemos: In the Name of the People (London, Lawrence \& Wishart).

Figa, J. (1997) 'Socializing the State: Civil Society and Democratization from Below in Slovenia’, in Bokovoy, M., Irivine J. A. \& Carol, L. S. (eds) (1997).

Fink-Hafner, D. (ed) (2015) The Development of Civil Society in the Countries on the Territory of the Former Yugoslavia Since the 1980s (Ljubljana: FDV).

Fisher, M. (2013) ‘Indirect Action: Some Misgivings about Horizontalism’, in Gielen, P. (ed) (2013).

Gielen, P. (ed) (2013), Institutional Attitudes: Instituting Art in a Flat World (Amsterdam: Valiz).

Gilbert, J. (2014) Common Ground: Democracy and Collectivity in an Age of Individualism (London, Pluto Press).

Golob, T. (2013) Uroš Lubej: Samo njim ni nič jasno, Playboy.si, 26 March 2013, available at: http://www.playboy.si/branje/intervju/uros-lubej-samo-njim-ni-nic-jasno/, accessed 7 January 2016.

Gračner, B. (2013) 2013 Slovenia’s ‘Zombie Uprising’, Counterfire, 1 March 2013, available at: http://www.counterfire.org/international/16323-slovenias-zombie-uprising, accessed 27 July 2016.

Gregorčič, M. (2005) ¡Alerta roja! Teorije in prakse onkraj neoliberalizma (Ljubljana: Študentska založba).

Horvat, S. \& Štiks, I. (eds) (2015) Welcome to the Desert of Post-Socialism: Radical Politics After Yugoslavia (London, Verso).

IDS (2015) O nas, available at: http://www.demokraticni-socializem.si/o-nas/, accessed 24 February 2015. 
IDS (2016) Koraki k demokratičnemu socializmu, available at: http://www.demokraticnisocializem.si/programski-dokumenti/program-ids-koraki-k-demokraticnemu-socializmu/, accessed 4 October 2016.

Isin, E. (2009) 'Citizenship in flux: the figure of the activist citizen', Subjectivity, 29. Jelušič, L. (2006) 'Civil Society in Slovenia: A Watchdog Against Militarisation of the Political State', in Caparini, M., Fluri, P. \& Molnar, F. (eds) (2006).

Katz, R. S. \& Crotty, W. (eds) (2006) Handbook of Party Politics (New York, Sage).

Kioupkiolis, A. (2010) ‘Radicalizing Democracy’, Constellations, 17, 1.

Kirn, G. (2014) 'Slovenia’s social uprising in the European crisis: Maribor as periphery from 1988 to 2012', Stasis, 2, 1.

Kirn, G., Kralj, G. \& Piškur, B. (eds) (2009) New Public Spaces: Dissensual Political and Artistic Practices in the Post-Yugoslav Context (Maastricht: Jan van Eyck Academie).

Kitschelt, H. (2006) ‘Movement Parties’, in Katz, R. S. \& Crotty, W. (eds) (2006).

Korsika, A. \& Mesec, L. (2014) 'Slovenia: From Spontaneous Protest to the Renewal of the Socialist Left', Kurswechsel, 1.

Kraft, M. G. (2015) 'Insurrections in the Balkans: From Workers and Students to New Political Subjectivities’, in Horvat, S. \& Štiks, I. (eds) (2015).

Krašovec, P. (2013) 'The Slovenian Uprising in Retrospect', Journal of Contemporary Central and Eastern Europe, 21, 2-3.

Kurnik, A. \& Beznec, B. (2009) 'Resident Alien: The Rog Experience on the Margin’, in Kirn, G., Kralj, G. \& Piškur, B. (eds) (2009).

Kriesi, H. (2015) 'Party Systems, Electoral Systems, and Social Movements’, in della Porta, D. \& Diani, M. (eds) (2015).

Kurnik, A. (2013) 'Artikulacije rabijo neartikuliran bes’, Časopis za kritiko znanosti, domišljijo in novo antropologijo, 254, pp. 11-19. 
Kuzmanić, T. (2002) Policija, mediji, UZI in WTC: Antiglobalizem in terorizem (Ljubljana, Mirovni inštitut)

Lorey, I. (2013) 'On Democracy and Occupation: Horizontality and the Need for New Forms of Verticality', in Gielen, P. (ed.) (2013).

Lukšič, I. (1990) 'K razpravi o civilni družbi: sprejem Gramscija v Jugoslaviji', Časopis za kritiko znanosti, domišljijo in novo antropologijo, 130, 1.

Maeckelbergh, M. (2009) The Will of the Many: How the Alterglobalisation Movement is Changing the Face of Democracy (London, Pluto Press).

Močnik, R. (2003) 'Social change in the Balkans', Eurozine, 20 March, available at: http://www.eurozine.com/articles/2003-03-20-mocnik-en.html, accessed 4 October 2016. Mouffe, C. (2013) Agonistics: Thinking the World Politically (London, Verso). Mouffe, C. (2014) ““Democratise democracy!” - Interview with Chantal Mouffe’, Transformations, 16 April 2014, available at: http://ransformations-blog.com/we-proposedemocracy-interview-with-chantal-mouffe/, accessed 3 October 2016.

Musić, G. (2013) 'Between Facebook and the Picket Line: Street Protests, Labour Strikes and the New Left in the Balkans', Journal of Contemporary Central and Eastern Europe, 21: 2-3.

Nemac, K. (2014) Vseslovenska vstaja - leto kasneje. mojpogled.com, 28 April 2014, available at: http://mojpogled.com/vseslovenska-vstaja-leto-kasneje/, accessed 7 January 2016.

Radio Krka (2013) VIDEO: Manifest Vseslovenske ljudske vstaje, 4 January, available at: http://www.radiokrka.com/poglej_clanek.asp?ID_clanka=174580, accessed 4 April 2016.

Razsa, M. \& Kurnik, A. (2012), ‘The Occupy Movement in Žižek’s hometown: Direct democracy and a politics of becoming', American Ethnologist, 39, 2. 
RTVSLO (2013) ‘Slovenija ima dobra izhodišča za demokratični socializem’, 30 April, available at: http://www.rtvslo.si/slovenija/slovenija-ima-dobra-izhodisca-zademokraticni-socializem/307815, accessed 7 April 2016.

Sitrin, M. A. (ed) (2006) Horizontalism: Voices of Popular Power in Argentina (Oakland, CA, A. K. Press).

Sitrin, M. A. (2012) Everyday Revolutions: Horizontalism and Autonomy in Argentina (London, Zed Books).

Sitrin, M. (2014) 'Goals without Demands: The New Movements for Real Democracy’, South Atlantic Quarterly, 113, 2.

Sitrin, M. \& Azzellini, D. (2012) Occupying Language: The Secret Rendezvous with History and the Present (New York, Zuccotti Park Press).

Sitrin, M. and Azzellini, D. (2014) They Can’t Represent Us! Reinventing Democracy from Greece to Occupy (London, Verso).

Slameršak, A. (2013) Slovenia on the Road to Periphery. The International MarxistHumanist, 25 June 2013, available at: http://www.internationalmarxisthumanist.org/articles/slovenia-road-periphery-aljoaslamerak, accessed 14 October 2015.

Solidarnost. 2016. Kdo smo. Available at: http://solidarnost.si/kdo-smo/ (11 January 2016).

Srnicek, N. \& A. Williams (2015) Inventing the Future: Postcapitalism and a World Without Work (London, Verso).

Štiks, I. (2015) “"New Left” in the Post-Yugoslav Space: Issues, Sites, and Forms, Socialism and Democracy, 29, 3.

Tormey, S. (2015) The End of Representative Politics (Cambridge, Polity). 
Vidrih, P. (2014) 'Bili smo zelo naivni, politika nas je izigrala’, Primorske novice, 18 April 2014, available at: http://www.primorske.si/Priloge/7--Val/-Bili-smo-zelo-naivni,-politikapa-nas-je-izigrala.aspx, accessed 7 January 2016.

Vodovnik, Ž. (2014) 'Demokratizacija in nova družbena gibanja', Teorija in praksa, 51, 2-3. Workers and Punks' University (2013) Democratic Socialism is the Future [in Slovenian] (Ljubljana, Institute for Labour Studies), available at: http://www.delavske-studije.si/wpcontent/uploads/2013/03/Prihodnost_je_demokraticni_socializem.pdf, accessed 1 December 2015.

Zadnikar, D. (2002) 'Nato in globalizacija’ in Gregorčič, M. \& Kovačič, G. (eds), Ne NATO - mir nam dajte! (Ljubljana, Mirovni inštitut).

Zdravković, L. (2014) 'Misliti nemogoče: onkraj predstavništva, Editirana transkripcija pogovornega večera v anarhističnem socialnem centru’, Časopis za kritiko znanosti, domišljijo in novo antropologijo, 257, pp. 53-66. 